\title{
Self-Employment and Economic Empowerment: A Case of Pot Makers'
}

\section{OPEN ACCESS}

Volume: 6

Issue: 4

Month: April

Year: 2019

ISSN: 2321-4643

Received: 12.03.2019

Accepted: 30.03.2019

Published: 01.04.2019

Citation:

Tigari, Harish, and K.P. Ashwini. "Self-

Employment and Economic Empowerment: A Case of Pot Makers'." Shanlax International Journal of Management, vol. 6, no. 4, 2019, pp. 1-8.

DOI:

https://doi.org/10.34293/management.v6i4.352

This work is licensed under a Creative Commons Attribution-NonCommercialNoDerivatives 4.0 International License

\author{
Harish Tigari \\ Faculty Member, Department of Commerce \\ Davangere University, Shivagangotri, Karnataka, India
}

\author{
K.P.Ashwini \\ PG Student, Department of Commerce \\ Davangere University, Shivagangotri, Karnataka, India
}

\begin{abstract}
The economic activity which is having profit motto called a business and person who engages in an economic activity termed as an entrepreneur. The livelihood of an individual always depends on earnings through paid employment or Self-employment. The risk with functionalism in paid employment is completely different, compared to self-employment. It is alternative employment which creates a platform for the development of an individual in their ways by creating new ideas, initiating with bearing the risk, assembling all factors of production with proper management, thereby an individual created first employment to him only. The term economic empowerment significantly promotes the individual capacity of women and men active involvement in economic activity; thereby they sustain themselves and get benefit from that growth. Here the present study mainly focused on the role of self-employment in economic empowerment of pot makers. The present attempts to analyze pot making activity, its cost structure, marketing of pots, and economics of pot making. For this, a structured questionnaire will be prepared to collect the primary data by the pot makers.
\end{abstract}

Keywords: self-employment, economic empowerment, pottery, socio-economic.

\section{Introduction}

The organization for economic coöperation and development defines the term Economic empowerment as the individual capacity of women and men to participate in, contribute to and benefit from growth processes in ways that recognize the value of their contributions, respect their dignity and make it possible to negotiate a fairer distribution of the benefits of growth. The term economic empowerment significantly promotes the capacity of women and men active involvement in economic activity; thereby they contribute themselves and get benefit from that growth. The prominence of industrialization creates employment generation, productive activities, self-employment, investment, and entrepreneurship. From last many more decades many informal sectors and organizations contributing new things for the economy. In that handcraft is a special and creative small scale sector. Which has the power to create many self-employment opportunities and it is passed from generation to generation? The kumbara community has the skills of pottery making, so they are started this creative art to lead their life by selling pots. Pottery making becomes a traditional occupation and it is sources of employment. It has become a solely depends activity. The pottery makers are not adopting any new technology and trends in this creative art. They are adopting the culture and traditional art; still, they are following the traditional methods of production of pots. 
The economic empowerment is possible by these types of independent workers and $80 \%$ of our country peoples are working in informal sectors including their own self-employment.

\section{Review of Literature}

(Kym E young 2002) ${ }^{1}$ The porter making very suits to the women apart from the men who practice the same work by comparing spirituality, social customs, and oral tradition. The study expressed the cultural traditions and development of pottery work. It is traditionally passed down through generation; it leads to getting self-employment.

(Kiara Maureen Hughes 2009) $)^{2}$ Pottery making is a contemporary production for global ethic art markets. It is a series of economic and social transformation. This dynamic art form included both women and men. Individual creativity and market recognition created in the market for both men and women. They can acquire the skills and become an independent producer. The development of pottery making is shaping the empowerment of men and women by their work.

(BulaSirika 2008) ${ }^{3}$ Artisan women are playing a significant role in socio-economic life. Their role is equally in sustainable development by making diversification. Their economic status adversely affected by some factors by challenging them. Here the author observes the economy of pottery making. They are structurally involved in traditional pottery making in their region. Pot making is a symbolic representation of the traditional business.

(G. Sudhakar, Mr. Myder Ali Baig and Dr.PrahaladRao 2013) ${ }^{4}$ Pottery making helps to earn a sustainable income to the family. They wish to carry their craft to their children. Pottery is a traditional, local, and environmentally sustainable activity. The hand-made art pottery is still practiced by a few of the oldest living generation. It is a prestigious occupation in historical days.

(Moriekaneko 2014) ${ }^{5}$ the study of pot makers study the characteristics of local knowledge and how its transmission from one generation to another generation. Different pot makers or handicrafts involved in a hand, and finger movements in different patterns of pottery making. It passes from generation to generation. The pottery learning process resulted in identifying the interaction between the potters with the natural environment and their social relationship.
(Alex Acheamong 2015) ${ }^{6}$ Pottery industry definitely demonstrates the traditional manufacturing techniques. Still being it is practicing by the many people for their livelihood. It is an attempt made for transferring the skills. The pottery making is a small-scale business comes under micro activity. These industries are contributing to the nation's development by offering and creating self-employment.

(Jabu. S. Haji 2016) ${ }^{7}$ Pottery productions is a potential activity which generates income for the poor household people. It is a reliable source for income generation, through building capacity of people, and improves the skills, knowledge, and attitude of people and improves the economic status of women. It fosters the opportunity to increase skills, education and remove poverty with self -dependent".

(Ritumani Haloi 2017) ${ }^{8}$ the socio-economic conditions of the pot makers are shifting to another profession because of the sustainability in the pottery industry. The author identified this backdrop and attempts to look at the socio-economic condition and poverty ratio of the specific group and identified the opportunities in the rural industrialization for livelihood.

\section{Economic Empowerment and Self-Employment}

In the modern economic era, a new form of entrepreneurship with new dimensions creates an opportunities door to the people to become a successor in economic activity with profit motto. The employment generation, productive activities, self-employment, investment, entrepreneurship are the common phenomena's which are closely associated with financial inclusion. The richness feeling by the nations with factors of production creates different ways for financial inclusion. It is a process of covering all population under monetary administration by providing income generation opportunities called an entrepreneurial occupation. A Self-employment is also a tool to create own employment by means employment by own with the independent role. It generates creative ideas, uniqueness, skills, and ability and provides the best experience to take strong decisions and providing a platform for exploring themselves. The empowerment perspective in any economic activity referred to as three-dimensional approaches 
which involve educational, sociological, and economic empowerment. The economic empowerment and self-employment, both are closely related and an associated variable majorly contributes to poverty eradication. The organization for economic coöperation and development defines the term economic empowerment as the capacity of individual women and men to take part in, give to and benefit from growth processes in ways that recognize the value of their contributions, respect their dignity and make it possible to negotiate a fairer distribution of the benefits of growth. The term economic empowerment significantly promotes the capacity of individual women and men active involvement in economic activity; thereby they contribute themselves and get benefit from that growth.

\section{Objectives of the Study}

1. To analyze the role of self-employment in economic empowerment.

2. To examine the socio-economic status of pot makers'.

\section{Problematization}

The pot makers are significantly treated as lowerincome people, and they do not want to adopt new technology in pottery production. They are not getting any higher economic benefits. Nowadays the pottery production is in a declining stage because of lack of education, cultural restriction and lack of updated technologies. Still, they are facing stiff competition by plastic products in the market, with a lack of institutional support. The present study intends to address these factors, with a socioeconomic fact sheet of pot makers. The present study attempts to analyze the problems and prospects pot makers in Harihar with intend to examine the role of pot making in economic empowerment.

\section{Need for the Study}

There are two factors which are significantly influenced by success or failure of any economic activity; such as a social and economic condition. The social condition describes the supportive environment and economic condition describes the individuals' economics. In this context, the present study examines the socio-economic condition of pot makers; determine how the activities of pottery making create self-employment and also attempts to analyze the problems and prospects of pot makers in Harihar city.

\section{The Methodology of the Study}

The present research considered and presented the data on the bases of the first hand and secondhand data. The research is completely focused on pot makers and derived the data by interaction and discussion, their personal or individual information collected through the questionnaire, direct interview made to know their socio-economic condition with the standard of living of pot makers. The secondary data is also base for our research which is collected from papers, articles, magazines, and websites.

\section{Scope and Limitations of the Study}

The study areas cover entire Harihar region, the scope of the sample population was restricted to Harihar and town confinement was made to the vastness of study as well as the constraints like individual investigators accessibility, availability of time. However to keep in mind the social responsibility of researcher the study areas was selected scientifically and representatively.

The following are the major limitations of the study.

- Due to academic work the researches has less work complete the task.

- The study is essentially a micro level study.

\section{Analysis and Interpretation}

Table 1: Demographics of potteries

\begin{tabular}{|l|c|c|}
\hline \multicolumn{1}{|c|}{ Gender } & Fq & $(\mathbf{\% )}$ \\
\hline Male & 14 & 70 \\
\hline Female & 06 & 30 \\
\hline Total & $\mathbf{2 0}$ & $\mathbf{1 0 0}$ \\
\hline Age & $\mathbf{F q}$ & $\mathbf{( \% )}$ \\
\hline More than 10 & - & - \\
\hline $10-20$ & - & - \\
\hline $20-30$ & - & - \\
\hline 30 and above & 20 & 100 \\
\hline Total & $\mathbf{2 0}$ & $\mathbf{1 0 0}$ \\
\hline Education & $\mathbf{F q}$ & $\mathbf{( \% )}$ \\
\hline Illiterate & 12 & 60 \\
\hline
\end{tabular}


International Journal of Management

\begin{tabular}{|c|c|c|}
\hline Primary & 8 & 40 \\
\hline SSLC & - & - \\
\hline PUC and above & - & - \\
\hline Total & 20 & 100 \\
\hline
\end{tabular}

Gender: commonly Women's are more work in the felid of pottery making. But in this research area, male respondents are more involved in the pottery making, because the heavy work like soil smoothing and primary activities of pottery making had done by males. Females were with supportive activities like finishing, firing, painting, etc.

Age: Pottery making was a traditional occupation, respondents who are worked in pottery making they attain the age of above 30 years, they started their journey of pottery making from the age of 13-15 years old. So they are well experienced in the pottery field.

Education: The pot makers who are responded, the majority they are illiterate and some respondents got the primary level of education. In olden days the people not supported to educate their children's. They provided training about self-employment.

Table 2: Pot fact sheet

\begin{tabular}{|c|c|c|}
\hline Employed ratio & $\mathbf{F q}$ & $(\%)$ \\
\hline Yes & 10 & 50 \\
\hline No & 10 & 50 \\
\hline Total & 20 & 100 \\
\hline PresentPottery & $\mathbf{F q}$ & $(\%)$ \\
\hline Yes & 16 & 80 \\
\hline No & 04 & 20 \\
\hline Total & 20 & 100 \\
\hline Years & $\mathbf{F q}$ & $(\%)$ \\
\hline Less than ten years & 00 & 00 \\
\hline $10-20$ & 02 & 10 \\
\hline $20-30$ & 02 & 10 \\
\hline 30 and above & 16 & 80 \\
\hline Total & 20 & 100 \\
\hline
\end{tabular}

Employment ratio: The half portion of the pot makers shifted their work from pottery making to other works. They do not completely depend on pottery making, but they are doing as a side business, another half portion of pot makers still depend on pottery making because they are illiterate they are not able or aware about other alternatives.
Present pottery making ratio: $80 \%$ of the respondents they are still following and doing pottery business through the traditional way. They are doing this pottery business for their livelihood if they stop, it is difficult to sustain. So for that reason, they are still depended on pottery business.

Years of pottery making: Almost all respondents have experience in pottery making more than 30 years. From their childhood, they are started and got training in pottery making. Now they can prepare any kind, any size of the pots in a minute without defect.

Table 3: Pot firm structure

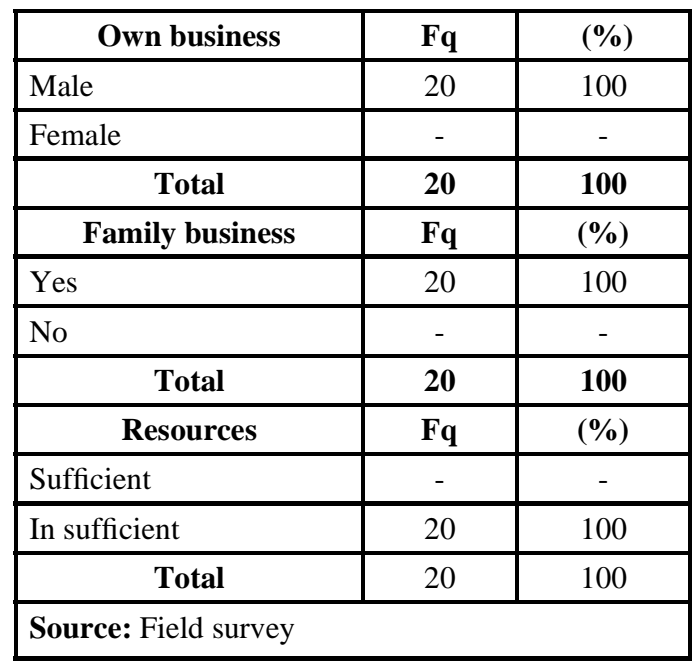

Own business: All respondents are working with their own pottery business. They are self-employed in their own activities of pottery making. They do not work under any other people. Within the family, they have developed skills in pottery making.

Family business: Pottery making will be developed from one generation to another generation. It is from heredity. All respondents continuing the same business from one decade to other decades.

Resources: The pot makers stated the opinion that there are no sufficient resources pot makers to manufacture pots. There is the very scarcity of resources i.e. soil as compared to ancient days. There is a resource problem facing by pot makers like transportation, marketing and etc. 
Table 4: Pot fact sheet

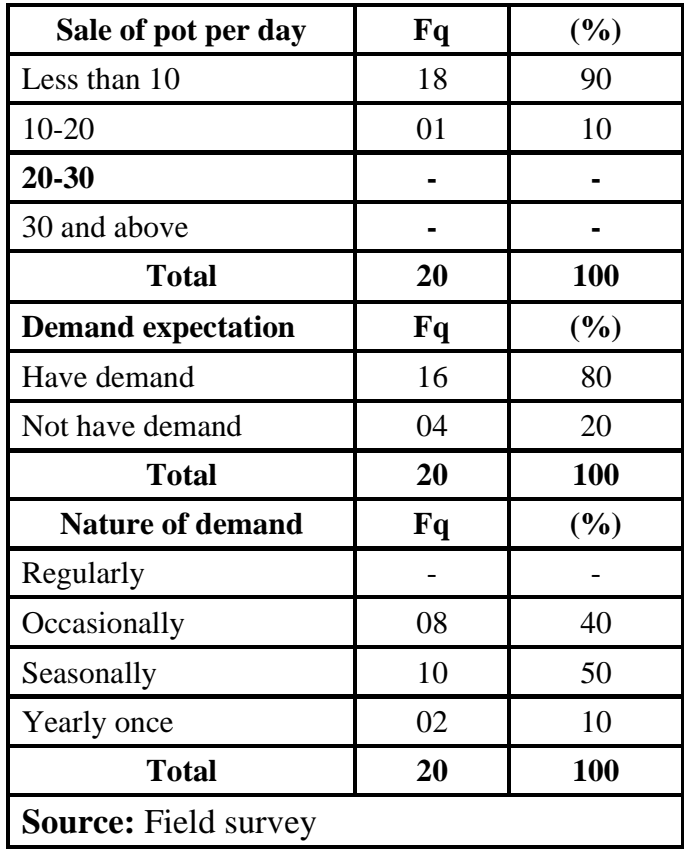

Sales of pot per day: There is very less demand for the pot throughout the year. They have the seasonal demand or occasional demand for the pots. So for that, per day they sold less than 10 potters, but in seasons they get high sales.

Demand expectation: The respondents say that there is a demand for the pot. But due to the lack of resources, they failed to meet demands. The major respondents gave an opinion that pottery has a high demand.

Nature of demand: There is no regular demand for the pots, in occasionally it will get some demand for certain days, and in summer it will get more demand to compare to another season, the demand ratio and nature are yearly once, not in every day of the year.

Table 5: Family, Dependency and Problems

\begin{tabular}{|c|c|c|}
\hline Family involvement & $\mathbf{F q}$ & $(\%)$ \\
\hline Involved & 16 & $80 \%$ \\
\hline Not-involved & 04 & $20 \%$ \\
\hline Total & 20 & 100 \\
\hline Other business dependency & $\mathbf{F q}$ & $(\%)$ \\
\hline Yes & 12 & $60 \%$ \\
\hline No & 08 & $40 \%$ \\
\hline Total & 20 & 100 \\
\hline
\end{tabular}

\begin{tabular}{|l|c|c|}
\hline \multicolumn{1}{|c|}{ Problems } & $\mathbf{F q}$ & $\mathbf{( \% )}$ \\
\hline Lack of sources & $\mathbf{0 8}$ & $\mathbf{4 0 \%}$ \\
\hline Lack of finance & - & - \\
\hline Support and demand & - & - \\
\hline All the above & 12 & $60 \%$ \\
\hline \multicolumn{1}{|c|}{ Total } & $\mathbf{2 0}$ & $\mathbf{1 0 0}$ \\
\hline Source: Field survey
\end{tabular}

Family involvement: The pottery making is the family business so all family members have skills and knowledge about pottery making. All family members are completely involved in pottery making activities as helpers.

Parallel employment: Nowadays due to many problems the pottery making is falling down. For their livelihood, people depend on this occupation. But the majority of people took this as a side business parallel employment.

Problems of pot makers: All respondents informed that they faced problems such as scared resources, financial problems, lack of support from the government, demand variations.

Table 6: Income,prospect \& employment

\begin{tabular}{|c|c|c|}
\hline Income & $\mathbf{F q}$ & $(\%)$ \\
\hline Getting & 10 & $50 \%$ \\
\hline Not getting & 10 & $50 \%$ \\
\hline Total & 20 & 100 \\
\hline Going concern & $\mathbf{F q}$ & $(\%)$ \\
\hline Yes & 12 & $60 \%$ \\
\hline No & 08 & $40 \%$ \\
\hline Total & 20 & 100 \\
\hline Employment & $\mathbf{F q}$ & $(\%)$ \\
\hline Agree & 20 & $100 \%$ \\
\hline Disagree & - & - \\
\hline Total & 20 & 100 \\
\hline
\end{tabular}

Income: the half part of the respondents stated that they are earning income and enjoying profit, and other $50 \%$ of people say that they do not earn any profit due to more expenditures and cost of production.

Going concern: Majority of respondents said they want to continue their business because they got this from traditionally so they don't want to leave that job, $40 \%$ respondents' state it is difficult to lead 
a life based on this so for that they don't want to continue this work.

Creating employment: All the respondents stated that they are doing their own and family business. They stated that it helps to create selfemployment. It is a riskless job and it motivates to develop their self.

Table 7: Cost Benefit Analysis of Pot Making

\begin{tabular}{|l|c|c|c|c|c|c|c|c|}
\hline \multicolumn{1}{|c|}{ Cost elements } & Rs.5 & Rs.10 & Rs.20 & Rs.40 & Rs.50 & Rs.120 & Rs.150 & Rs.200 \\
\hline Raw-materials & 02 & 05 & 10 & 15 & 25 & 50 & 75 & 100 \\
\hline Transportation & 02 & 03 & 05 & 15 & 15 & 75 & 25 & 075 \\
\hline Marketing & 01 & 02 & 05 & 10 & 10 & 25 & 50 & 025 \\
\hline Labour TPC & - & - & - & - & - & - & - & - \\
\hline \multicolumn{1}{|c|}{} & $\mathbf{0 5}$ & $\mathbf{1 0}$ & $\mathbf{2 0}$ & $\mathbf{4 0}$ & $\mathbf{5 0}$ & $\mathbf{1 2 0}$ & $\mathbf{1 5 0}$ & $\mathbf{2 0 0}$ \\
\hline Cost of sale (without profit) & 5 & 10 & 20 & 40 & 50 & 120 & 150 & 200 \\
\hline \% of profit & 05 & 02 & 05 & 10 & 10 & 5 & 25 & 25 \\
\hline Credit sales & - & - & - & - & - & - & - & - \\
\hline TSC(with profit) & $\mathbf{1 0}$ & $\mathbf{1 2}$ & $\mathbf{2 5}$ & $\mathbf{5 0}$ & $\mathbf{6 0}$ & $\mathbf{1 2 5}$ & $\mathbf{1 7 5}$ & $\mathbf{2 2 5}$ \\
\hline Estimated PC & 15 & 25 & 30 & 60 & 70 & 150 & 180 & 250 \\
\hline Future demand & 20 & 30 & 50 & 75 & 80 & 175 & 200 & 260 \\
\hline
\end{tabular}

Source: Field surveyTPC: total production cost, TSC: total selling cost

\section{Cost-Benefit Analysis}

The cost elements will be classified as raw materials, transportation, market, labour and etc. Here the cost is divided based on a size of pots. For very small size pot they are getting cost of Rs.5, they sell pot with the same cost without profit but with Rs.5 additional amount as a profit, they sell per pot with profit. In the future, the estimated cost of pot making increased amounting to Rs.15 and demand will also increase up to Rs.20. The cost of raw materials, Transportation, Marketing cost is a divide in the proportion of 2:2:1 without labor cost because the pot makers are self-employed. It applied to all kind of the following costs. For other small size pots, they incurred Rs.10 with an additional amount of Rs. 2 as profit. It sells with a cost of Rs. 12 with profit. The estimated cost will incur up to a maximum of Rs. 25 with a demand for Rs.30.The big size of pots incurred the cost of Rs.20 at present and now it is selling with a profit of Rs.5 and total selling cost with margin of the profit has become Rs.25. The pot makers estimated that in future the cost will be incurred of Rs.30 with demanding of selling cost of Rs.50.The average or medium sized pots incurred Rs.40 as per today's cost. Here they fix some high profit to earn a high profit with more sales of these sizes of pots. They fix the profit of Rs.10 and sell it into Rs.50. In the future, they increase cost as the same portion of profit i.e. Rs.60and future demand also increases to these pots up to Rs.75.Above these big sizes of pots, the cost will be described. It means there is a big size of pots with making the cost of Rs.50 and the same Rs.10 is fixing as a profit. Sell it with a profit of Rs.60 and the future demand may increase up to Rs. 80 by incurring Rs.70. Other than normal size the pots which will use occasionally. These pots are in very big size so it incurs the cost of Rs.120. with profit portion of Rs.5 because it does not have huge demand and in future, it may incur Rs. 150 for the scarcity of resources. And the pot makers demand up to rs.180. This Pot which is in a different shape with large size and uses for traditional purpose and occasionally these pots incurred cost of Rs. 150 to make. The pot makers fixed the profit percentage of Rs. 175 at present and in next days it may incur Rs. 180 and it will get demand in the range of Rs.200. The last size in pot cost is fixed with Rs. 200 with additional profit of Rs.25 the pot sell with total cost with the profit of Rs.225 and in future, some more expenditure is incurred so the cost will increase up to Rs.250 and future demands will be at Rs.260. 


\section{Findings}

- Employment: many pot makers leave pot making process. They will be depending on other works for livelihood. More respondents are doing other business or work and not self-employment

- Family business: The respondents have their own and family business. It will transfer from one generation to another generation. It is traditionally followed from the last decades.

- Experience: Pot makers have 30-40 years of experience in pottery making. They have skills in pottery designing and training from their childhood.

- The scarcity of resources: There are more problems which are facing by the pot makers. Lack of finance, raw materials, no support from the government and others.

- Demand: They have demand for pots but the pot makers not able to reach the demand because of the above problems. Some respondents getting huge profit from pottery but it will possible only seasonally and occasionally. The pot makers are still in low economic status and difficult to manage.

\section{Suggestions}

- Government support: The government should support the pot makers to increase their wealth, place, and for development of their economic status. Solve the problems and should provide facilities for resources. If it gets good support from government and society it helps for the development of self-employment.

- Short term education and training: The education is very necessary to know the conditions and positions of the modern era. And increase the ability to face problems and train to develop them. It should create a platform for the pot makers.

\section{Conclusion}

The finality of the study confined role of selfemployment in economic empowerment in the changing global business environment. It has been significantly attributed by the rise of neoliberals with free entry and exit, the borderless relationship between countries enacted as globalization, and the new dimension with a pivotal role in the economy called as financialization, alternatively financial inclusion by covering all people in financial administration by providing opportunities to become self-employed or paid employed. The organization for economic coöperation and development defines the self-employment as the employment of employers, workers who work for themselves, members of producers' co-operatives, and unpaid family workers. The latter are unpaid in the sense that they lack a formal contract to receive a fixed amount of income at regular intervals, but they share in the income generated by the enterprise (OECD). In Indian scenario there is a requirement to promote conventional self-employment activities by assisting in technological now-how, finance, and other infrastructural facilities.

\section{References}

Akilandeeswari Pottery Industry and Its Development By Effective Marketing Through Information and Communication Technologies (ICT) "International Journal of research granthaalayah" et.al., vol. 4, (Iss. 4: SE): April 2016, ISSN-2350-0530 (O) ISSN-23943629 (P), Impact factor: 2.035 (I2OR)

Alex Acheampong "B.A communication design" (PG 9272713).

Bula Sirika, Socio-economic Status of Handicraft Women among Macca Oromo of West Wallaga, Southwest Ethiopia, Ethiop. J. Educ. \& Sc. vol. 4, no. 1, Sep., 2008.

Haji, Jabu Sharif, "Women Livelihood Improvement through Small Scale Pottery Production at Kiembesamaki Zanzibar". Masters thesis, The Open University of Tanzania. 2016.

Kiara Maureen Hughes, "The Women Potters of Mata Ortiz: Growing Empowerment through Artistic Work", UNM Digital Repository, 2009.

Kym. E. Young, "McNair Scholars Journal", vol. 3, 2002.

Morie KANEKO, I Know How To Make Pots By Myself": Special Reference To Local Knowledge Transmission in Southwestern Ethiopia, African study monographs, suppl. 48:59-75, Mar., 2014.

Okhiria Adebimpe, "Pottery production, an entrepreneurship perspective for job creation and poverty alleviation. A case study of Dada pottery, 
Okelele", Ilorin, Kwara State, Nigeria Journal of economic and sustainable development" ISSN:2222-1700 (paper) ISSN: 2222-2855 (online), vol. 6, no. 2, 2015.

PrabhakarKotte., \&Srendra, M., “An Anthropological Study of Kummara Community in Naidupalem Village, Nellore District, AP, India "Imperial Journal of Interdisciplinary Research (IJIR)", vol. 2, no. 12, 2016, ISSN: 2454-1362.

Ritumani Haloi, Potters, Profession and their Livelihood Opportunity under Rural Industrialization: A Quantitative Analysis (IJHSSS)", ISSN:2349 6959 (online), ISSN:2349-6711 (print), vol. 3, no. v, March, 2017, page no.139-150, http://www.ijhsss.com
Shakila Halifan Mteti, Engendering Pottery Production and Distribution Processes among the Kisi and Pare of Tanzania, "International Journal of Gender and Women's studies" Dec., 2016, vol. 4, no. 2. pp. 127-141, ISSN: 2333-6021(Print), 2333-603X (online).

Sini. M "Arts \& education international research journal": vol. 3, no. 1, 2016.

Sudhakar, G., Mirza Hyder., \& Prahalad Rao, "Design and Development of a Pottery Making Machine by Using New Product Design and Development Techniques", http://www. researchgate.net/publication/264045564, Dec., 2013, DOI: $10.3850 / 978-981-07-8860-5$

\section{Author Details}

Mr.Harish Tigari, Faculty Member, Department of Commerce, Davangere University, Shivagangotri, Karnataka India.Email Id: hstkplr148@gmail.com.

Ms.K.P.Ashwini, PG Student, Department of Commerce, Davangere University, Shivagangotri, Karnataka, India 